\title{
Bill Morphology Does Not Influence Vocal Performance in Darwin's Small Tree Finch on Floreana Island
}

\author{
Rebekah Christensen, Sonia Kleindorfer* \\ (School of Biological Sciences, Flinders University, GPO Box 2100, Adelaide, SA 5001, Australia)
}

\begin{abstract}
Bird song is used for mate attraction and is important for establishing reproductive isolation. Current research highlights performance constraints on song production that may be influenced by variation in bill morphology. Darwin's finches are a model system for studying the relationship between morphology and song performance, with previous studies suggesting that lower vocal performance is correlated with larger bill size. Here, we tested for a relationship between bill morphology and vocal performance in Darwin's Small Tree Finch (Camarhynchus parvulus) on Floreana Island. We found no evidence of a correlation between bill morphology and vocal performance. This finding is in agreement with prior study of the Small Tree Finch, but contrasts a greater body of work addressing song in Darwin's Finches. We discussed our findings in the context of ecological divergence, and ecological variation across species.
\end{abstract}

Key words: Darwin's finches; Bill morphology; Small Tree Finch; Song; Vocal performance

\section{澳大利亚 Floreana 岛达尔文小树雀喙型与其鸣唱的不相关性}

\author{
Rebekah Christensen, Sonia Kleindorfer* \\ (School of Biological Sciences, Flinders University, GPO Box 2100, Adelaide, SA 5001, Australia)
}

\begin{abstract}
摘要: 鸟类鸣唱的功能通常是吸引配偶, 对于建立繁殖隔离也是非常重要的。现有的研究认为鸟类鸣唱表演 可能受到鸟类喙型变化的影响。达尔文鸣雀是一类用来验证喘型和鸣唱表演关系的模型物种, 前人的研究认为较 低的元音演奏与更大的喙相关。本文用在 Floreana 岛屿生活的达尔文小树雀(Camarhynchus parvulus)来验证嚎型和 元音演奏的关系。结果显示, 喙型大小与元音演奏之间无相关性。这个发现与过去对小树雀中的研究结果相似, 但却与达尔文鸣雀中更大体型的鸟类研究结果相反。讨论了研究结果在物种的生态分化和生态变异之间的前后关 系。
\end{abstract}

关键词: 达尔文鸣雀; 喙型; 达尔文小树雀; 鸣唱; 元音演奏

中图分类号: Q959.739; Q959.739.05 文献标识码：A 文章编号：0254-5853-(2009)04-0423-06

Bird song has received attention for its role as a mating signal, and thus for its potential to contribute to reproductive isolation and the speciation process (e.g. Irwin, 2000; Huber \& Podos, 2006; Seddon \& Tobias, 2007). A growing body of research highlights the links between morphological variation and song variation, suggesting that divergence in morphological traits that have ecological significance (e.g. bill morphology) may also influence song divergence (Palacios \& Tubaro, 2000; Podos, 2001; Ballentine, 2006; Huber \& Podos, 2006).

While bird song is produced when air passes over the syrinx causing vibration of the tympaniform membranes; the size, shape, and movements of the vocal tract play a significant role in filtering harmonic overtones resulting in the characteristic pure tone sound of birdsong (Nowicki, 1987; Westneat et al, 1993; Beckers et al, 2003). For each sound frequency produced, there is an optimal configuration of the vocal tract, and thus the vocal tract must be reconfigured for each change in frequency (Nowicki, 1987). Because of this need to reconfigure the vocal tract, in birds with trilled song there is a tradeoff between the range of frequencies that can be produced (frequency bandwidth) and how fast a bird can sing (trill rate)(Podos, 1997). At slower trill rates, there is greater opportunity for movement of the vocal tract and hence a greater range of frequencies may be produced. In contrast, at faster trill rates there is less time for vocal tract reconfiguration, resulting in a narrow frequency bandwidth. For a given trill rate, there is an upper limit or optimum bandwidth that can be produced 
(Fig. 1). Songs that are close to this upper limit are deemed as being of high vocal performance, while songs that are distant from this upper limit are deemed as being of lower performance (Podos, 1997).

Vocal performance has been examined in a range of songbirds, with studies suggesting it can be linked with male quality (e.g. Ballentine et al, 2004), and also constrained by morphology (e.g. Podos, 2001). Interestingly, a study of eight species of Darwin's finches demonstrated a correlation between bill morphology and vocal performance such that larger billed and larger bodied species had lower levels of vocal performance (Podos, 2001). Similarly, vocal performance was correlated with bill morphology at the intraspecific level in the Medium Ground Finch (Geospiza fortis), with larger billed individuals having lower vocal performance (Podos, 2001). In contrast, in a population of Darwin's Small Tree Finch (Camarhynchus parvulus) on Santa Cruz Island vocal performance was not correlated with bill morphology (Christensen et al, 2006).

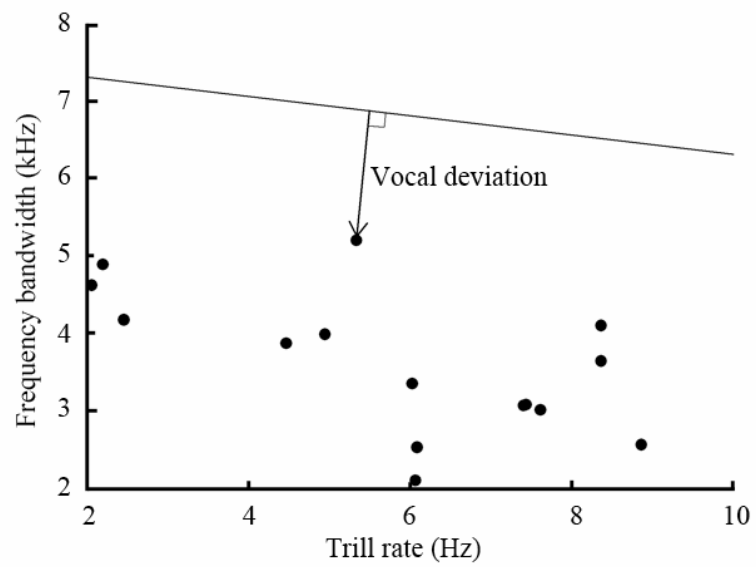

Fig. 1 Tradeoff between trill rate $(\mathrm{Hz})$ and frequency bandwidth $(\mathrm{kHz})$ in the Small Tree Finch on Floreana Island

The performance limit is represented by the upper bound regression calculated by Podos (1997) for all Emberizidae (y $=-0.124 x+7.55)$. Vocal performance is measured as the orthogonal deviation from the upper limit.

Darwin's finches are an appropriate group in which to examine the role of bill morphology in constraining song as they have a broad variation in bill morphology both within and across species. In addition, song functions in mate choice hence understanding patterns of song variation can be useful in understanding patterns of mate choice. Here, we examine the relationship between bill morphology and vocal performance in the Small Tree Finch on Floreana Island. Previous studies of Darwin's Finches predict clear correlations between bill size and vocal performance such that larger billed birds will have lower vocal performance (even at the intraspecific level)(Podos, 2001; Podos \& Nowicki, 2004). However, given previous findings suggesting no correlation between vocal performance and bill size in the Small Tree Finch on Santa Cruz Island (Christensen et al, 2006), in this study we predict no correlation between bill size and vocal performance.

\section{Materials and Methods}

\subsection{Morphology}

The Small Tree Finch is a socially monogamous species, which occurs preferentially in the moist highland forest of the Galapagos Islands. We worked across the breeding seasons of 2004 (12-19 February), 2005 (1-19 February) and 2006 (28 February-8 April) on Floreana Island. Our study site was approximately 2 ha and was located in the highland forest at the base of Cerro Pajas $\left(001^{\circ} 17^{\prime} \mathrm{S}, 090^{\circ} 27^{\prime} \mathrm{W}\right)$.

We undertook widespread mistnetting in all years, and each captured individual was given a unique combination of color bands and a numbered aluminium band. We took the following morphological measurements using dial calipers: (1) bill length (from the anterior edge of the nare) $(\mathrm{mm}),(2)$ bill depth at base $(\mathrm{mm}),(3)$ bill width at base (mm), and (4) tarsus length ( $\mathrm{mm})$. (5) Wing length $(\mathrm{mm})$ was measured using a wing ruler.

\subsection{Song recording}

Small Tree Finch song is simple, consisting of one note or syllable that is repeated (Bowman, 1983; Podos, 2001; Fig. 2). We have not observed different song types within the study population, and a previous study of the Small Tree Finch on Santa Cruz Island demonstrated no annual variation in an individuals song characteristics (Christensen et al, 2006). Song recordings were made using a Sony DCD-100 DAT Recorder and Sennheiser ME 80 Directional Microphone. Recordings were obtained systematically at nests and opportunistically for colour banded males throughout the study site $(n=15)$. In this study we analyzed 5-10 individual songs per male depending on the male's singing intensity, which influenced the number of quality recordings we obtained for each male. Songs were edited using Peak 4.11 (Bias Inc. Software) to select the best field recordings.

\subsection{Vocal performance}

Vocal performance is defined by the tradeoff between the speed of song production (trill rate), and the range of frequencies that can be produced (frequency bandwidth). Thus, it is measured as the orthogonal 


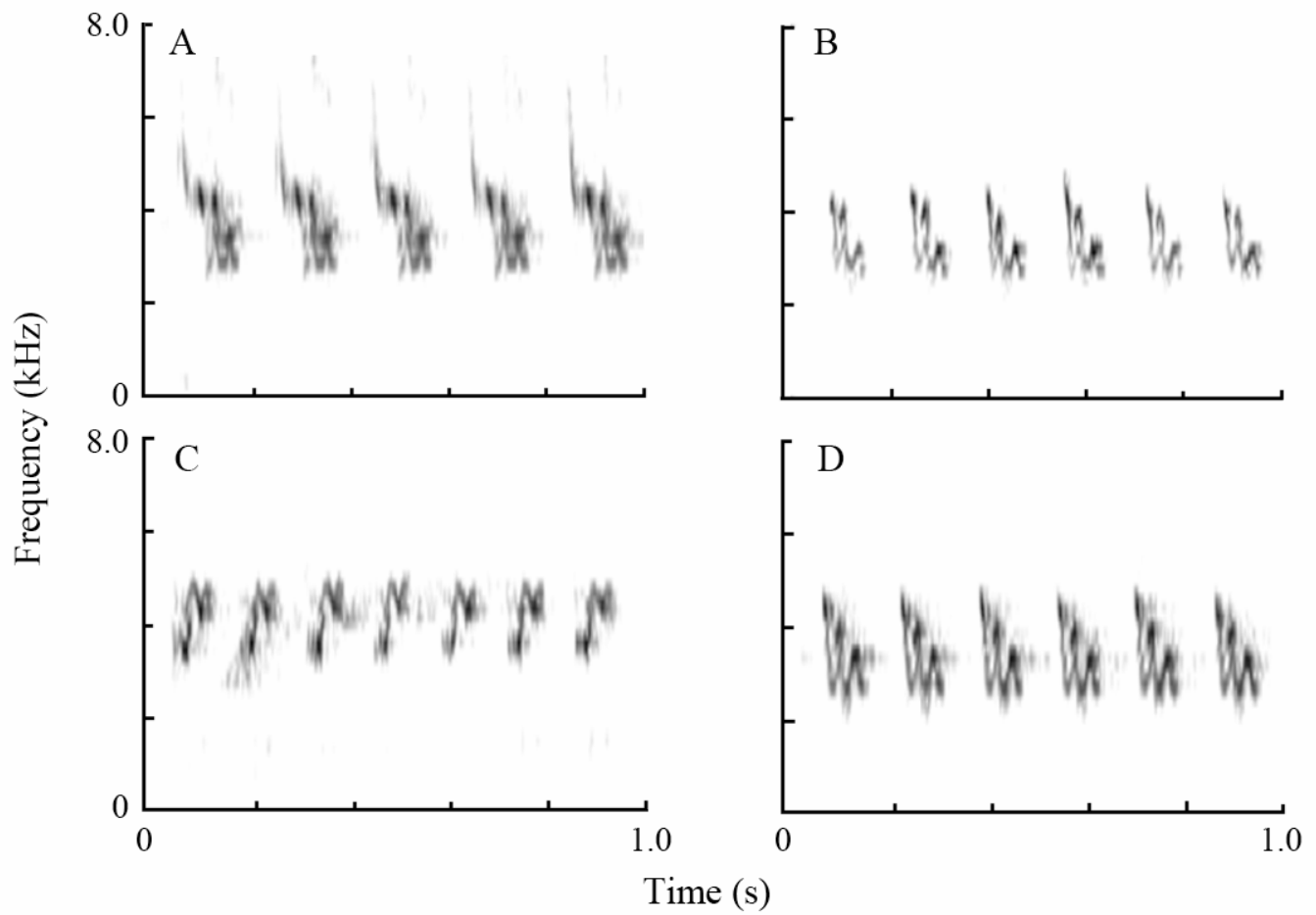

Fig. 2 Representative sonograms of four male Small Tree Finches on Floreana Island

A: Individual SK604; B: Individual SK709; C: Individual SK1172; D: Individual SK1529.

deviation from an upper performance limit defined by this tradeoff (Fig. 1). To determine vocal performance, we first calculated trill rate. Using Raven 1.2 for MacOSX (Cornell Bioacoustics program, Ithaca, NY, USA, Charif et al, 2004) we calculated the length of the syllable plus intersyllable interval. Trill rate $(\mathrm{Hz})$ is the number of syllables per second, and was calculated by dividing 1 by the length of the syllable plus intersyllable interval.

Frequency bandwidth $(\mathrm{kHz})$ was determined using Canary 1.2.4 for MacOS9 (Cornell Bioacoustics program, Ithaca, NY, USA, Charif et al, 1995). Frequency bandwidth was defined as the range of frequencies with amplitudes within $24 \mathrm{~dB}$ of the frequency with peak amplitude. This criterion is thought to include all the relevant elements of the acoustic signal while excluding unnecessary background noise (Staicer, 1996; Podos, 1997; Hoese et al, 2000). We noted the lowest and highest frequencies $(\mathrm{kHz})$ within the $24 \mathrm{~dB}$ range and then calculated the difference between these to determine frequency bandwidth. The mean of each song parameter (frequency bandwidth, trill rate) was calculated for each individual and these values were used in subsequent calculation of vocal performance.

We plotted frequency bandwidth as a function of trill rate (Fig.1) in accordance with standard methods (Podos, 2001; Ballentine et al, 2004; Beebee, 2004). To define the upper performance limit, we used the upper bound regression determined by Podos (1997) for the family Emberizidae (Fig. 1). As Darwin's finches (Geospizinae) are phylogenetically nested within the emberizids, the use of this limit is appropriate (Podos, 2001). We then calculated the orthogonal deviation of each data point (song) from the upper bound regression (Fig. 1). This "vocal deviation" is a measure of vocal performance - songs with greater deviation from the upper limit have lower vocal performance, while those close to the upper limit have high vocal performance.

\subsection{Statistical analyses}

All statistical analyses were undertaken using SPSS 13.0.0 for Mac OSX. We used tarsus length and wing length as independent variables in regression analyses to test for correlations between body size and each bill morphology variable. The body and bill size variables were also used as independent variables in regression analyses to test for correlations between morphology and vocal performance.

\section{Results}

\subsection{Bill and body morphology}

Means $\pm S D$ of morphological variables are shown in Tab. 1 for: (1) all banded individuals in the study population, and (2) individuals included in analysis of morphology and vocal performance. Using data for all 
banded small tree finches on Floreana Island $(n=125)$, we found significant correlations between body size (tarsus length and wing length) and all bill size variables (bill length: $R=0.24, F=3.83, P=0.02$; bill depth: $R=0.36$, $F=9.03, P<0.01$; bill width: $R=0.47, F=17.24, P<0.01)$. Given the strong correlations between body and bill size, we regressed each bill variable onto tarsus length (as an indicator of body size) and used the residuals of these regressions in subsequent analyses of vocal performance in relation to morphology.

\subsection{Song and morphology}

Means $\pm S D$ of trill rate, frequency bandwidth, and vocal performance for the 15 Small Tree Finches included in this analysis are shown in Tab. 1. We found no significant correlations between either tarsus length or wing length, and vocal performance ( $n=15$; tarsus length: $R=0.29, F=1.20, P=0.30$; wing length: $R=0.15, F=0.28$, $P=0.61)$. There were no significant correlations between vocal performance and any of the individual bill variables ( $n=15$; bill length: $R=0.16, F=0.33, P=0.58$; bill depth: $R=0.34, F=1.67, P=0.22$; bill width: $R=0.23$, $F=0.71, P=0.42$ ). Similarly, there were no significant correlations between any of the bill size residuals (to control for the non-independence of bill and body size) and vocal performance $(n=15$; bill length residual: $R=0.12, F=0.20, P=0.66$; bill depth residual: $R=0.31$, $F=1.34, P=0.27$; bill width residual: $R=0.48, F=3.89$, $P=0.70)$.

Tab. 1 Mean $\pm S D$ and range of morphology and song variables for the Small Tree Finch on Floreana Island

\begin{tabular}{|c|c|c|c|c|}
\hline & \multicolumn{2}{|c|}{ Individuals for song analysis $(n=15)$} & \multicolumn{2}{|c|}{ All banded individuals $(n=125)$} \\
\hline & Mean $\pm S D$ & Range & Mean $\pm S D$ & Range \\
\hline Bill length (mm) & $(7.30 \pm 0.37)$ & $6.60-7.90$ & $(7.30 \pm 0.32)$ & $6.60-8.00$ \\
\hline Bill depth (mm) & $(7.15 \pm 0.24)$ & $6.70-7.50$ & $(7.12 \pm 0.27)$ & $6.50-8.25$ \\
\hline Bill width (mm) & $(6.29 \pm 0.22)$ & $6.00-6.70$ & $(6.27 \pm 0.23)$ & $5.80-7.35$ \\
\hline Tarsus length (mm) & $(20.28 \pm 0.77)$ & $19.00-21.75$ & $(20.11 \pm 0.68)$ & $18.00-21.60$ \\
\hline Wing length (mm) & $(61.60 \pm 1.54)$ & $59.00-64.50$ & $(61.48 \pm 1.98)$ & $56.00-69.50$ \\
\hline Frequency Bandwidth $(\mathrm{kHz})$ & $(3.61 \pm 0.91)$ & $2.10-5.20$ & & \\
\hline Trill rate $(\mathrm{Hz})$ & $(5.84 \pm 2.27)$ & $2.05-8.86$ & & \\
\hline Vocal deviation & $(3.19 \pm 0.77)$ & $1.68-4.66$ & & \\
\hline
\end{tabular}

Morphology variables are shown for all banded individuals $(n=125)$ and for the subset of individuals used in analyses of song and morphology $(n=15)$. Summary statistics of song variables are calculated for the 15 individuals used in the analyses in this paper.

\section{Discussion}

In the context of divergence and speciation, there is growing interest in the role of morphology in influencing song characteristics. In most models of speciation, a common challenge is connecting the buildup of ecological divergence with reproductive isolation (Schluter, 2000; Coyne \& Orr, 2004; McKinnon et al, 2004). However, if mating signals (such as bird song) diverge as a byproduct of divergence in ecological traits (such as the bill), then this challenge is largely overcome (Schluter, 2000; McKinnon et al, 2004).

Darwin's finches are well known for the diversity of bill form and function displayed within the group. Long-term studies of the ecology and evolution of Darwin's finches have highlighted the role of natural selection in shaping bill morphology, and have greatly informed current understanding of evolutionary theory (Grant, 1999; Grant \& Grant, 2008). In particular, in Darwin's Ground Finches, there are well-studied correlations between bill size, and the size and hardness of seeds a bird can consume efficiently (reviewed in
Grant, 1999; Grant \& Grant, 2008). Given the diversity of bill morphology and function in Darwin's Finches, it is not surprising that recent study has also focused upon the role of bill morphology in influencing song characteristics. Podos (2001) first demonstrated a correlation between bill size and vocal performance across eight species of Darwin's Finches such that the larger billed species had lower vocal performance. In this same study, vocal performance was correlated with bill morphology in a population of the Medium Ground Finch, and again larger billed individuals had lower vocal performance (Podos, 2001). Further study of the Medium Ground Finch has also provided evidence that vocal performance is 'constrained' by bill morphology in this species (Huber \& Podos, 2006). In contrast to these studies, here, we found no evidence of a correlation between vocal performance and bill morphology in the Small Tree Finch on Floreana Island. This finding is in agreement with previous study of the Small Tree Finch on Santa Cruz Island, where there was also no relationship between bill morphology and vocal performance (Christensen et al, 2006). On Santa Cruz 
Island, male Small Tree Finches that sang songs with higher vocal performance had greater pairing success suggesting that vocal performance may be an indicator of male quality (Christensen et al, 2006). Vocal performance has also been linked with indicators of male quality, or with female choice in other songbirds (e.g. Ballentine et al, 2004). However, there is insufficient data available for the Small Tree Finch on Floreana Island to assess the role of male vocal performance in pairing success or as an indicator of male quality.

The mixed results of studies of vocal performance and bill morphology in Darwin's Finches may be explained by the variation in foraging modes within the group. Darwin's Ground Finches are primarily granivorous, and it is within this group that there is the strongest evidence for a role of bill morphology in constraining vocal performance (Podos, 2001; Huber \& Podos, 2006). In contrast, Darwin's Tree Finches are primarily insectivorous, and thus far there is little to no evidence for a role of bill morphology in constraining vocal performance (Christensen et al, 2006; Christensen $\&$ Kleindorfer, in prep.). Granivory and insectivory require different and specialized bill morphology and musculature, and these differences may result in a

\section{References:}

Ballentine B. 2006. Morphological adaptation influences the evolution of a mating signal [J]. Evolution, 60: 1936-1944.

Ballentine B, Hyman J, Nowicki S. 2004. Vocal performance influences female response to male bird song: An experimental test[J]. Behav Ecol, 15: 163-168.

Beckers GJL, Suthers RA, ten Cate C. 2003. Pure-tone birdsong by resonance filtering of harmonic overtones[J]. Proc Natl Acad Sci USA,100: 7372-7376.

Beebee MD. 2004. Variation in vocal performance in the songs of a Wood-Warbler: Evidence for the function of distinct singing modes[J]. Ethology, 110: 531-542.

Bowman RI. 1983. The evolution of song in Darwin's finches[M]// Bowman RI, Berson M, Leviton AE. Patterns of Evolution in Galapagos Organisms. San Francisco: American Association for the Advancement of Science, 237-537.

Charif RA, Clark CW, Fristrup KM. 2004. Raven 1.2 User's Manual [M]. Ithaca NY: Cornell Laboratory of Ornithology.

Charif RA, Mitchell S, Clark CW. 1995. Canary 1.12 User's Manual [M]. Ithaca NY: Cornell Laboratory of Ornithology.

Christensen R, Kleindorfer S, Robertson JGM. 2006. Song is a reliable signal of bill morphology in Darwin's small tree finch, Camarhynchus parvulus, and vocal performance predicts male pairing success [J]. J Avian Biol, 37: 617-624.

Coyne JA, Orr HA. 2004. Speciation [M]. Sunderland MA: Sinauer Associates, Inc.

Farnsworth A, Lovette IJ. 2005. Evolution of nocturnal flight calls in migrating wood-warblers: apparent lack of morphological differing correlation between bill morphology and vocal performance with the Ground versus the Tree Finches (Podos \& Nowicki, 2004). Further study of song and morphology in Darwin's Finches may provide greater insight in the role of bill morphology in constraining song production.

Acknowledgements: We thank the Galapagos National Park Service and the Charles Darwin Research Station for the opportunity to work on the Galapagos Archipelago, and TAME airlines for reduced airfare. This study was funded by Flinders University (Research Establishment Grant to SK, Overseas Field Trip Grant to RC), Conservation International and the American Bird Conservancy with awards to SK, and the Australian Federation of University Women SA with a Barbara Crase Bursary to RC. Many thanks to Rachael Dudaniec, Jody O'Connor, Jeremy Robertson, and Carlos Vinueza for their invaluable assistance in the field. We are particularly grateful to the Cruz and Wittmer families, and the community of Puerto Velasco Ibarra, Floreana Island, for their hospitality, transport assistance, and support.

constraints [J]. J Avian Biol, 36: 337-347.

Grant PR. 1999. Ecology and Evolution of Darwin's Finches . Rep ed .[M]. Princeton NJ: Princeton University Press.

Grant PR, Grant BR. 2008. How and Why Species Multiply: The Radiation of Darwin's Finches[M]. Princeton NJ: Princeton University Press.

Hoese WJ, Podos J, Boetticher NC, Nowicki S. 2000. Vocal tract function in birdsong production: Experimental manipulation of beak movements [J]. J Exp Biol, 203: 1845-1855.

Huber SK, Podos J. 2006. Beak morphology and song features covary in a population of Darwin's finches (Geospiza fortis) [J]. Biol $j$ Linnean Soc, 88: 489-498.

Irwin DE. 2000. Song variation in an avian ring species [J]. Evolution, 54: 998-1010.

McKinnon JS, Mori S, Blackman BK, David L, Kingsley DM, Jamieson L, Chou J, Schluter D. 2004. Evidence for ecology's role in speciation [J]. Nature, 429: 294-298.

Nowicki S. 1987. Vocal tract resonances in oscine bird sound production: evidence from birdsongs in a helium atmosphere [J]. Nature, 325: 53-55.

Palacios MG, Tubaro PL. 2000. Does beak size affect acoustic frequencies in woodcreepers [J] ? Condor, 102: 553-560.

Podos J. 1997. A performance constraint of the evolution of trilled vocalizations in a songbird family (Passeriformes: Emberizidae) [J]. Evolution, 51: 537-551.

Podos J. 2001. Correlated evolution of morphology and vocal signal structure in Darwin's finches [J]. Nature, 409: 185-188. 
Podos J, Nowicki S. 2004. Beaks, adaptation, and vocal evolution in Darwin's finches [J]. BioScience, 54: 501-510.

Schluter D. 2000. The Ecology of Adaptive Radiation [M]. New York: Oxford University Press

Seddon N, Tobias JA. 2007. Song divergence at the edge of Amazonia: An empirical test of the peripatric speciation model [J]. Biol $J$
Linnean Soc, 90: 173-188.

Staicer CA. 1996. Acoustical features of song categories of Adelaide's Warbler (Dendroica adelaidae) [J]. Auk, 113: 771-783.

Westneat MW, Long JH Jr, Hoese W, Nowicki S. 1993. Kinematics of birdsong: Functional correlation of cranial movements and acoustic features in sparrows [J]. J ExpBiol,182: 147-171.

\section{上海海洋大学水产动物营养繁殖学研究团队简介}

水产动物营养繁殖学团队是上海海洋大学水产养殖国家重点学科的骨干研究力量之一, 也是省部共建 水产种质资源发掘与利用教育部重点实验室的重要组成部分。

健康苗种是水产养殖业的重要物质基础, 因此苗种生产是水产养殖的重要研究内容之一。本团队负责 人成永旭教授在国内最早提出 “水产动物营养繁殖学” 的基本概念, 因此主编全国首部十一五规划教材 《水 产动物营养繁殖学》 (中国农业出版社, 待出版)。成永旭教授先后师从我国著名水产养殖专家一谭玉钧 教授、著名甲壳动物学家一堵南山教授和李少菁教授, 从事甲壳动物繁殖生物学和营养繁殖学的研究工作, 是蟹类营养繁殖学的开拓者之一。

团队负责人成永旭教授自 1998 年开始组建自己的实验室和研究团队, 目前研究团队形成了甲壳动物 繁殖生物学、蟹类营养繁殖学、生物饵料培养技术及生态毒理学、高效生态养殖技术集成这四个稳定的研 究方向, 研究品种主要包括中华线螯蟹、三病梭子蟹、瘤背石磺、糠虾、文蛤、克氏原螯虾和沙塘鳢等重 要水产经济动物。近十年来, 他所领导的团队对中华线螯蟹脂类营养繁殖学的进行了开拓性研究, 建立了 中华线螯蟹生殖性能和苗种质量的评价指标，初步阐明了中华线螯蟹性早熟的脂类营养机理，这初步奠定 了我国蟹类营养繁殖学的学术地位，其中该团队发明的河蟹“性早熟综合控制法”、“土池低盐度生态育苗 技术”、“河蟹强化育肥技术”已在上海、江苏、安徽、江西等省市大面积推广, 取得了显著的经济效益和 社会效益。近年来, 该团队又开始对三病梭子蟹、远海梭子蟹和美国蓝蟹等海水经济蟹类的繁殖技术和营 养繁殖学进行研究, 取得了一定的学术成果。鉴于该团队在蟹类增养殖技术和繁殖生物学的学术影响, 该 研究团队将负责承办 “2009 年国际经济蟹类生物学及增养殖技术研讨会”。此外, 该研究团队在瘤背石磺 和糠虾的繁殖生物学和养殖技术上也进行了较系统的研究。相关研究成果并多次应邀在国际学术会议上进 行主题报告, 并得到关注和好评。这些研究成果还分别得到了科技部和上海市科技成果转化基金的资助。

目前，该团队拥有教师 5 名，其中教授 2 人，副教授 2 人，是一支以中青年教师为主的创新型团队。 该团队拥有研究生 20 余名, 其中博士研究生 5 人, 已经毕业研究生 20 余名。目前, 该团队与澳大利亚、 美国和比利时等多家大学和研究所建立较广泛的科研合作和人员交流。

最近五年来，该团队主持国家自然科学基金面上项目 4 项、上海市科委重大攻关项目 2 项、上海市科 委重点基础研究项目 1 项、上海市农委科技兴农重点项目 2 项等重要项目, 总科研经费近 600 万元; 参与 的科研项目先后获得上海市科技进步奖二等、三等各一次; 在核心期刊上发表学术论文 120 多篇, 其中 SCI 论文 14 篇; 主编或参编国家级教材 3 部; 申请专利 10 项，获得授权专利 1 项。

成永旭, 吴旭干，杨䈠珍，王春，曾朝曙 